\title{
Review Article \\ Geotechnical Distinction of Landslides Induced by Near-Field Earthquakes in Niigata, Japan
}

\author{
Hirofumi Toyota and Susumu Takada \\ Department of Civil and Environmental Engineering, Nagaoka University of Technology, Nagaoka, Niigata 940-2118, Japan \\ Correspondence should be addressed to Hirofumi Toyota; toyota@vos.nagaokaut.ac.jp
}

Received 23 December 2014; Revised 2 March 2015; Accepted 13 March 2015

Academic Editor: Hamid R. Pourghasemi

Copyright ( $) 2015$ H. Toyota and S. Takada. This is an open access article distributed under the Creative Commons Attribution License, which permits unrestricted use, distribution, and reproduction in any medium, provided the original work is properly cited.

Landslides triggered by near-field earthquakes with epicentres directly beneath towns have attracted intense attention since the 2004 Mid-Niigata (Niigata-ken Chuetsu) Earthquake. Hilly and mountainous areas sustained heavy damage. Social problems developed when many towns became isolated because landslides cut off traffic and public service lifelines. Soil from landslides closed river channels and formed natural dams. The natural dams submerged some towns. Emergency measures were undertaken promptly to prevent debris flows caused by natural dam breaks. Subsequently, the 2007 Mid-Niigata Offshore (Niigata-ken Chuetsuoki) Earthquake and the 2011 Northern Nagano Earthquake struck the Niigata region. Landslides triggered by those earthquakes differed in terms of their number, scale, and location. Therefore, characteristics of the landslide sites of the respective earthquakes were examined to ascertain their topographical and geological features. Furthermore, differences in groundwater level and damage related to compound disasters were explained for discussion of the stability progress of damaged slopes.

\section{Introduction}

Niigata prefecture is located in western and central Japan (Figure 1). In the midlands of Niigata, the Chuetsu region, various natural disasters have frequently struck in recent years. At 17:56 on 23 October, 2004, the Mid-Niigata (Niigataken Chuetsu) Earthquake, the main tremor of which had a magnitude of 6.8, struck central Niigata-ken (Chuetsu area) and severely damaged the infrastructure of hilly and mountainous areas including Kawaguchi town, Ojiya city, Nagaoka city, and their environs. Numerous landslides occurred especially in the "Yamakoshi area" (Figure 1). That village was isolated by the cutting of all roads and infrastructural lifelines. The epicentral thrust-fault earthquake had a hypocentre of about $13 \mathrm{~km}$ depth, with characteristic frequent strong aftershocks that engendered further damage. In addition, rainfall of more than $100 \mathrm{~mm}$ was recorded from typhoon number 23 , which had passed through the Chuetsu region three days priorly. Data from the Japan Meteorological Agency (JMA) indicated that the daily rainfall of 21 October 2004 at Nagaoka city reached $115 \mathrm{~mm}$. Under those circumstances, more than 3,000 landslides occurred in the hilly area close to the seismic centre during the earthquake. The Japan Society of Civil Engineers [1] and Toyota et al. [2] reported specific damage caused by the disaster. Moreover, Tsukamoto et al. [3] and Rathje et al. [4] estimated the ground movement caused by landslides during the earthquake using investigation or remote sensing data. Geological and geomorphological features and special distributions of landslides in this area were reported by Chigira and Yagi [5] and Wang et al. [6]. Analyses of landslides including discontinuous dip layer were conducted by Onoue et al. [7] and Deng et al. [8]. They assumed that the landslides had been triggered by increase of pore water pressure in seam layers [9] and analysed the displacement using cyclic loading test results or Newmark's method [10].

Heavy snow fell during the two winters following the Mid-Niigata Earthquake. Yearly snowfall is usually about $400 \mathrm{~cm}$ in Nagaoka, but it reached nearly $700 \mathrm{~cm}$ per year in each of the two years following the earthquake. The snow in one year was the heaviest in 19 years. The collapsed slopes 


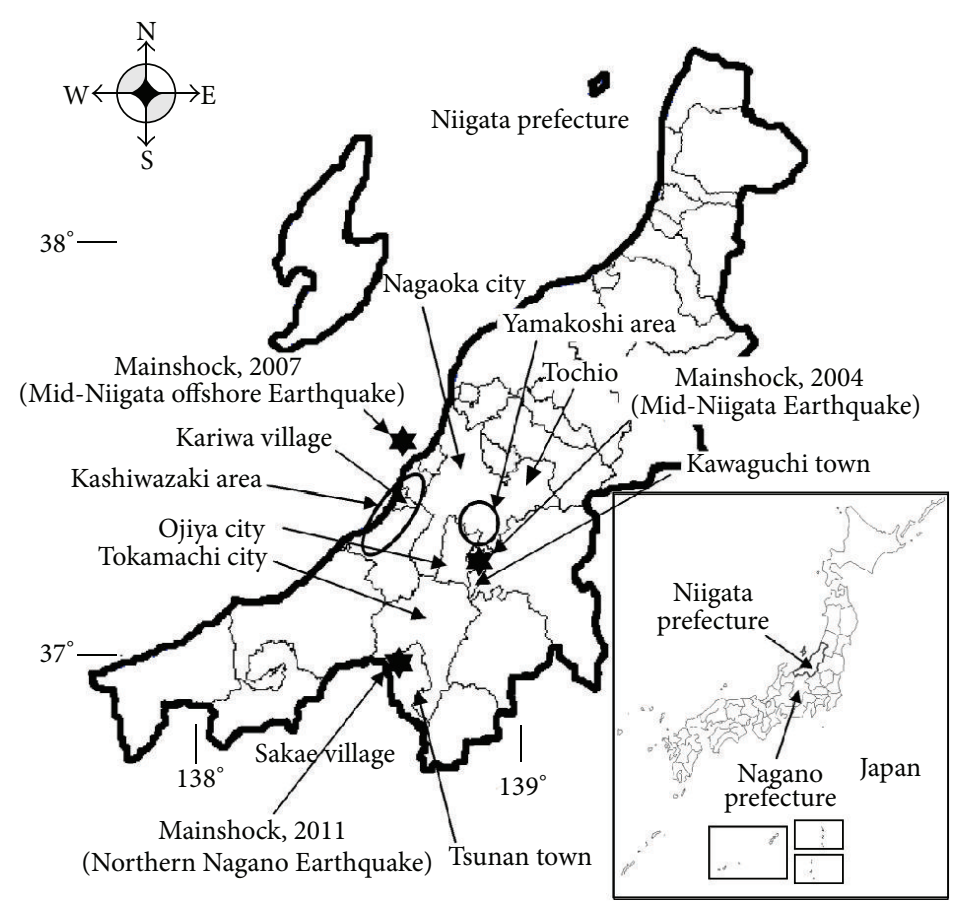

FIGURE 1: Map of Niigata prefecture.

exhibited interesting behaviour during snow and snowmelting seasons. Actually, this region has been notorious as a tertiary type landslide area. Landslides have frequently occurred in April and May: the snow-melting season.

Just three years after the Mid-Niigata Earthquake, at 10:30 on 16 July 2007, the Mid-Niigata Offshore (Niigata-ken Chuetsu-oki) Earthquake, the main tremor of which had a magnitude of 6.8 , struck offshore about $30 \mathrm{~km}$ northwest of the epicentre of the Mid-Niigata Earthquake. The earthquake was caused by a thrust fault with a hypocentre of about $17 \mathrm{~km}$ depth. The JMA Seismic Intensity was recorded as "upper 6 " in Kashiwazaki city, Nagaoka city, and Kariwa village. Major landslides were concentrated almost entirely along the "Kashiwazaki area" coastline (Figure 1). Earthquake damage was reported by the JGS [11], Onoue and Toyota [12], and Toyota and Onoue [13].

At 3:59 on 12 March 2011, immediately after the 2011 off the Pacific coast of Tohoku Earthquake (14:46 on 11 March 2011) [14], another earthquake (designated as the Northern Nagano Earthquake) occurred at the border of Nagano and Niigata prefectures [15]. Its main tremor had a magnitude of 6.7. The earthquake, caused by a thrust fault, had a hypocentre of about $8 \mathrm{~km}$ depth. The JMA Seismic Intensity was recorded as "upper 6" in Sakae village (Figure 1). Some landslides occurred in Sakae village, Tokamachi town, and Tsunan town under the remaining snow conditions.

For those successive earthquakes which occurred in close proximity, the landslide types are investigated for each earthquake and are compared considering the importance of groundwater levels on landslides. Moreover, the actual conditions of compound natural disasters were examined in the Chuetsu area to assess the compounded damage of these successive natural disasters.

\section{Geological and Geomorphological Features}

In the Chuetsu region, thick alluvium covers plains; hilly areas are composed mainly of soft mudstone of quaternary and tertiary deposits (Figure 2). Quaternary deposits are new strata formed from 2 million years ago. Tertiary deposits are geological structures formed between 24 million and 2 million years ago. The geomorphology formed by folding presents a prominent landslide area in this region.

The Chuetsu region was originally notorious as a tertiary type landslide area [16]. This area has been struck by many natural disasters in recent years. In the Chuetsu area, including Nagaoka and Ojiya (Figure 1), thick alluvium covers the Niigata plain created by the Shinano River. Hilly areas are composed mainly of soft mudstone of quaternary and tertiary deposits. This region has been compressed along the northwest-southeast axis because of crustal movements. Its folded mountains present prominent landslide configurations such as the cuesta landform. Earth-related disasters are generally concentrated in the "West Hills" and "East Hills" (Figure 2). The latter region includes a catchment area dotted with many ponds and rice terraces.

Tertiary mudstone is distributed in the Tokamachi and Tsunan areas, which are near the Northern Nagano Earthquake epicentre. This geology resembles that of the East Hills and is also notorious as a tertiary type landslide area. Nevertheless, it is interesting that Andesitic rocks mainly compose mountainous areas in the northern part of Nagano 


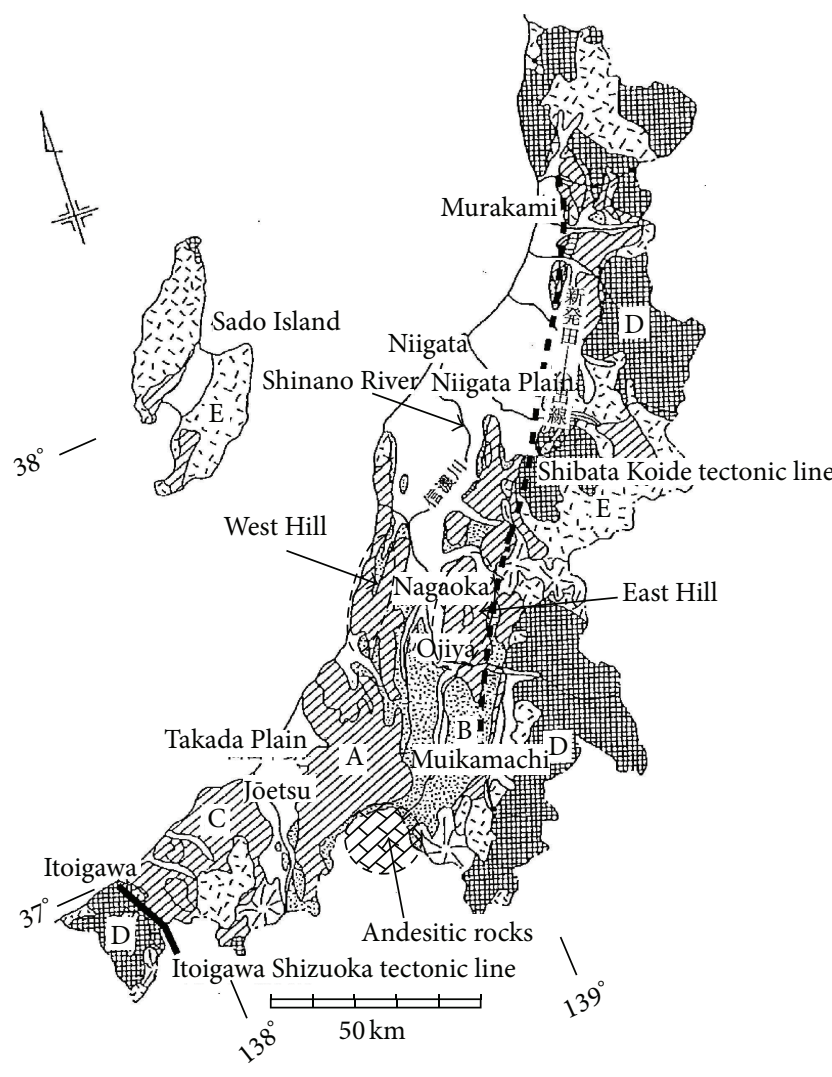

$\square$ Alluvial deposits
Volcanic rocks
Sedimentary rocks $]$ Quaternary
W Neogene
Paleogene $]$ Tertiary
四 Bedrocks

FIGURE 2: Geological map of Niigata [16].

when crossing the prefectural border separating Niigata and Nagano (Figure 2).

\section{Characteristics of Landslides}

\subsection{The Mid-Niigata Earthquake}

3.1.1. Old Landslides. "Tanesuhara," "Mushigame," and "Asahikawa" in Yamakoshi area have been described as representative designated landslide areas. Figure 3 presents a landslide map of those areas during the Mid-Niigata Earthquake provided by the Geospatial Information Authority of Japan (GSI). River-clogging landslides along the Imo River during the earthquake are the "Terano," "Nampei," "Naranoki," "Higashi-takezawa," and "Junidaira" landslides from upstream (Figure 3). Among those landslides, Terano and Higashi-takezawa were large-scale landslides, which required urgent countermeasures against river clogging.

Table 1 presents the number of landslides occurring during 1949-2002 around Yamakoshi area [16]. Many landslides occurred in the Asahi River basin, extending from Mushigame, and in the Ohta River, which has Yomogihira
TABLE 1: Number of landslides during 1949-2002.

(a) Classified by basin

\begin{tabular}{lc}
\hline & Number of landslides \\
\hline Asahi River & 29 \\
Ohta River & 19 \\
Nanataki River & 19 \\
Imo River & 17 \\
\hline
\end{tabular}

(b) Classified by region

\begin{tabular}{lc}
\hline & Number of landslides \\
\hline Asahikawa & 32 \\
Tanesuhara & 15 \\
Mushigame & 7 \\
\hline
\end{tabular}

and Nigorisawa as designated landslide areas. Although 17 landslides occurred in the Imo River basin, almost all occurred in the Tanesuhara or Nakano landslide area located upstream. Landslides were reportedly only a few in Nampei, Higashi-takezawa, or Junidaira, where natural dams were created as a result of the earthquake. When classified by region (Table 1(b)) from most to least numerous, they are Asahikawa, Tanesuhara, and Mushigame.

The history of the former Yamakoshi village is well recorded [17]. Its history from 1700 indicates Tanesuhara as the site of the greatest recorded earth-flow disaster. Table 2 shows records of landslides in Tanesuhara. The landslides are only recorded in Tanesuhara because no such large villages existed in Yamakoshi area. Although landslides in prehistoric times are unknown, the first landslide recorded in Tanesuhara occurred in 1824. An exogenous factor causing landslides is snow-melt water in early spring. At that time, slopes were destroyed and two large clogging ponds were created in the Imo River. About a century after that event, a landslide occurred during the snow-melting season at almost the same place, thereby forming a natural dam. During the Mid-Niigata Earthquake, which occurred about 80 years after the previous event, the river-clogging landslide was broken at Terano near Nakano. The decisive difference is that the expected exogenous factor was not snow-melt runoff, but an earthquake. As described above, river clogging caused by landslides is a common phenomenon in the Imo River of Tanesuhara because large landslides that clog the river have occurred every century.

3.1.2. Geological Features. Related to unrecorded landslides of prehistoric times, the landslide history of Yamakoshi area was investigated using a topographical map that was compiled using information from an aerial photograph. Figure 4 portrays landslide locations during the Mid-Niigata Earthquake presented on the map of old landslide topography (provided by the National Research Institute for Earth Science and Disaster Prevention (NIED) and the Japan Science and Technology Agency (JST) [18]) in Yamakoshi area. Moreover, the figure was overlaid on a simplified geological map provided by Takeuchi et al. [19] and on landslide-designated areas obtained from a conservation map of Niigata prefecture [20]. 


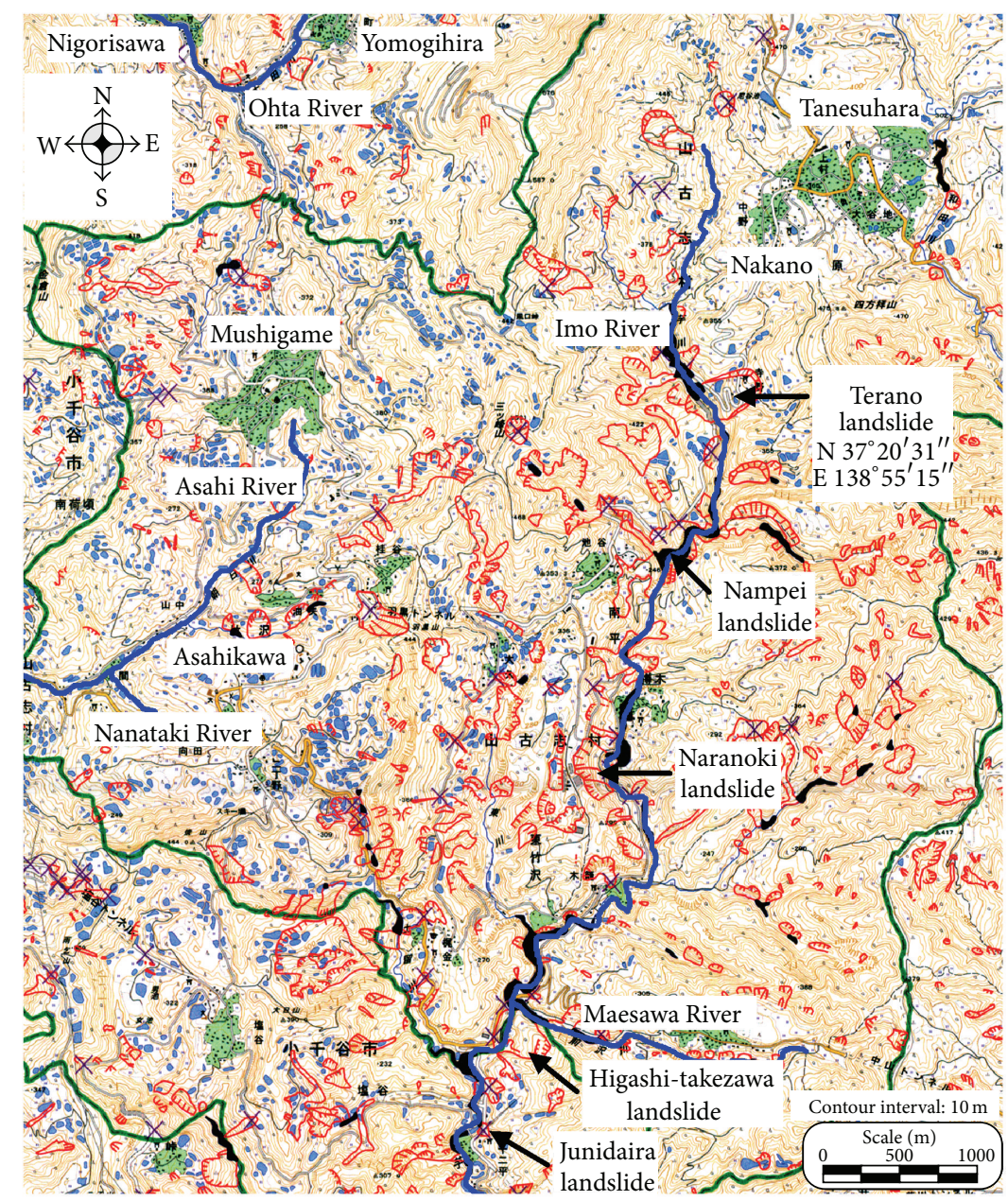

FIGURE 3: Disaster map around Yamakoshi area during Mid-Niigata Earthquake (provided by GSI).

TABLE 2: Old landslides in Yamakoshi area.

\begin{tabular}{lllll}
\hline Number & Year & Disaster & Place & Conditions \\
\hline 1 & $\begin{array}{l}1824 \\
\text { April: thawing } \\
\text { season }\end{array}$ & $\begin{array}{l}\text { Landslide } \\
\text { length } 1.4 \mathrm{~km}, \\
\text { width } 700 \mathrm{~m}\end{array}$ & Nakano & $\begin{array}{l}\text { Disaster throughout the village. 50\% of rice fields could } \\
\text { not be cultivated. Flood induced by river clogging. Two } \\
\text { ponds of } 100 \mathrm{~m} \text { length and } 10 \mathrm{~m} \text { depth were created. }\end{array}$ \\
\hline $\begin{array}{l}1926 \\
\text { May }\end{array}$ & $\begin{array}{l}\text { Landslide } \\
\text { length } 1.1 \mathrm{~km}, \\
\text { width } 180 \mathrm{~m}\end{array}$ & Nakano & $\begin{array}{l}\text { Fields and mountains of more than } 2 \mathrm{~km}{ }^{2} \text { were } \\
\text { damaged. Floods induced by river clogging. }\end{array}$ \\
\hline 4 & April & $\begin{array}{l}\text { Landslide } \\
\text { width } 50 \mathrm{~m}\end{array}$ & Terano & $\begin{array}{l}\text { Prefectural route (Tochio-Ojiya) was severed; bridge } \\
\text { collapsed. River clogging is unclear. }\end{array}$ \\
\hline
\end{tabular}

Many designated landslide areas are located in the East Hill area. Large-scale landslides that occurred during the earthquake such as those of Terano or Higashi-takezawa might be of a reactivated type of landslide because they coincide completely with the old landslide topography [18].

The west side of the map, which is classified in the Asahi River basin (Figure 4), is geologically an Araya deposit: massive dark grey mudstone. At the eastern side of the map, the Imo River basin (Figure 4), the deposit changes to alternating sandstone and massive mudstone, designated as Kawaguchi and Wanatsu deposits. Alternation of sandstone and mudstone is distributed mainly along the Imo River, except in its upper course. As presented in Figure 4, more numerous landslides occurred during earthquakes in areas with alternated layers of sandstone and mudstone than in areas with massive mudstone deposits. This finding implies that sandy natural slopes are more fragile than clayey natural slopes during earthquakes. However, landslide-designated 


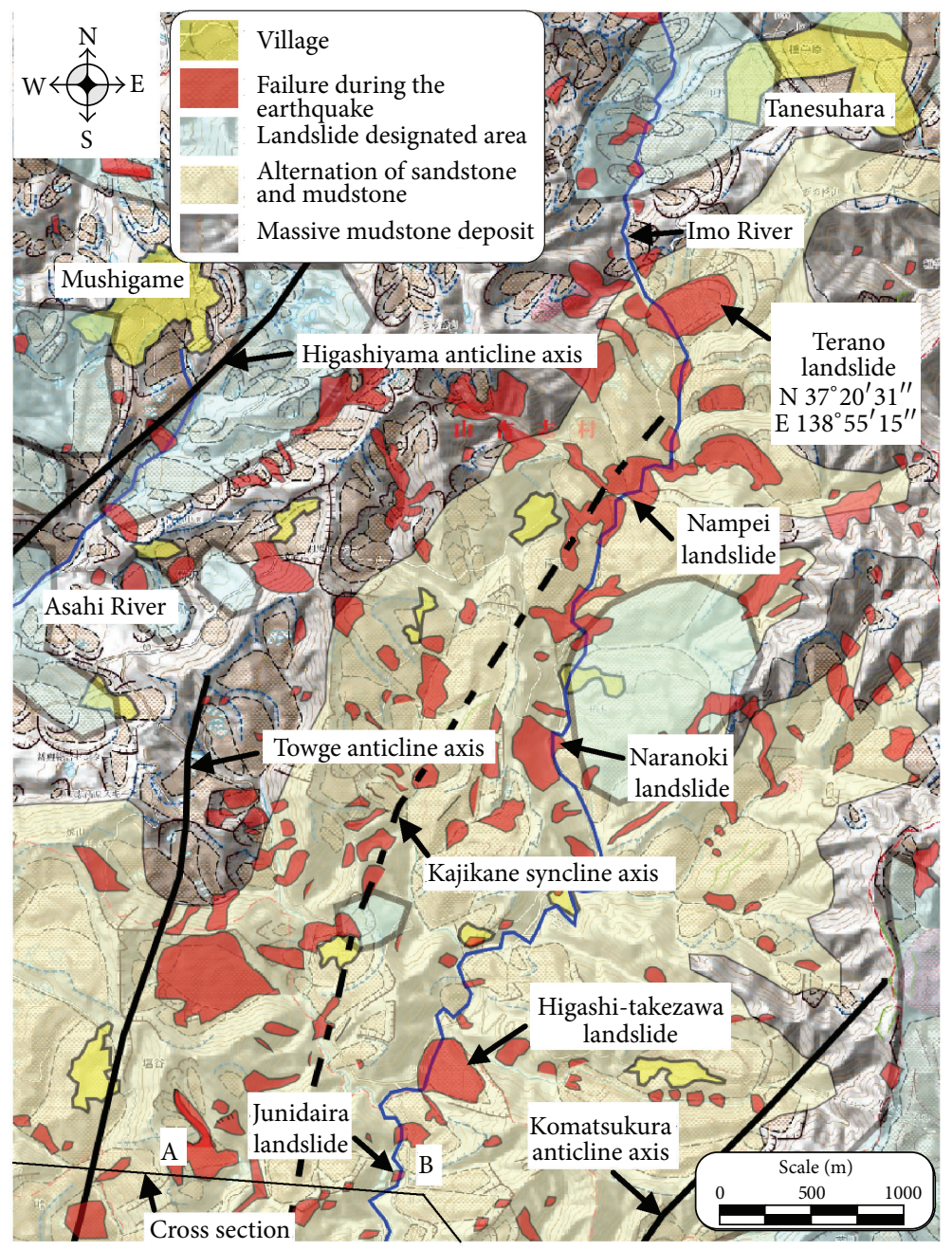

FIGURE 4: Landslide distribution and geological map around Yamakoshi area during Mid-Niigata Earthquake (provided by NIED and JST).

areas, in which landslides are induced by snowmelt waters, are distributed mainly in the massive mudstone deposits. Moreover, the notable geological features of this region are syncline and anticline structures. They form a complex topography in which synclinal axes and anticlinal axes are arranged with a short interval (Figure 4). For that reason, peculiarly cuesta topography is apparent in this region. Fragile and weak slopes are therefore formed easily. In addition, the river scours the riverbed and the slope toe. Thereby, the slope becomes unstable. For those reasons, it is considered that numerous landslides occurred during the earthquake.

Figure 5 depicts a geological cross section of the area south of Yamakoshi area (Junidaira) published by the National Institute of Advanced Industrial Science and Technology (AIST). The location of this sampled geological profile is presented in Figure 4. Sandstone (W) and sandy mudstone $\left(\mathrm{S}, \mathrm{Ku}_{2}\right)$ are distributed widely around the Imo River. This representative folded mountain area is composed of syncline and anticline. Geological cross sections clarify that a dip slope is apparent on the left bank of the Imo River. A reversedip slope is apparent on the right bank of the river. Peculiar slope failures occurred at the right and left banks of the Imo
River. Surface failures occurred frequently at the right bank having reverse-dip slope strata, whereas problematical large landslides occurred occasionally at the left bank, which is a dip gentle slope.

3.2. Mid-Niigata Offshore Earthquake. According to a report of the Ministry of Land, Infrastructure, Transport and Tourism (MLIT) given on 6 August 2007, 108 slope failures occurred during the Mid-Niigata Offshore Earthquake. The main slope failure sites are concentrated in the steep slope of coastal terrace from Shiiya to Hijirigahana, which is about $25 \mathrm{~km}$ distant, as shown in Figure 6. Although almost all slides were surface collapses, large mass movements rarely occurred in inland areas as described in Toyota and Onoue [13] because the earthquake occurred not under a mountainous area but under an offshore area. The fault extended from the epicentre to the south. However, the landslides are much fewer than the more than 3,000 which occurred during the Mid-Niigata Earthquake, despite the similarity of the earthquakes.

3.3. Northern Nagano Earthquake. The earth-slide disasters during the earthquake were not perfectly clear because 


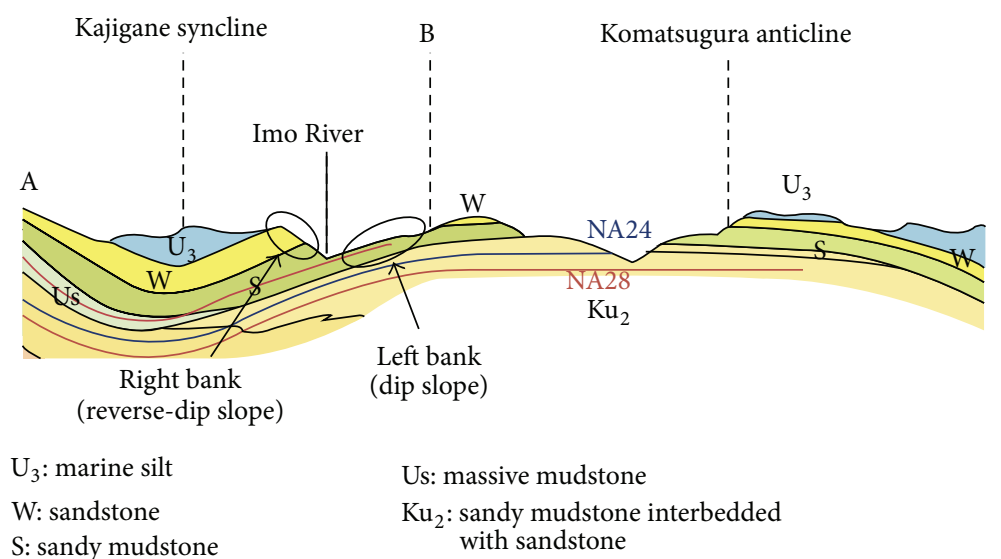

FIGURE 5: Geological cross section of the south of Yamakoshi area published by the National Institute of Advanced Industrial Science and Technology (AIST).

Mainshock (7/16 10:13)
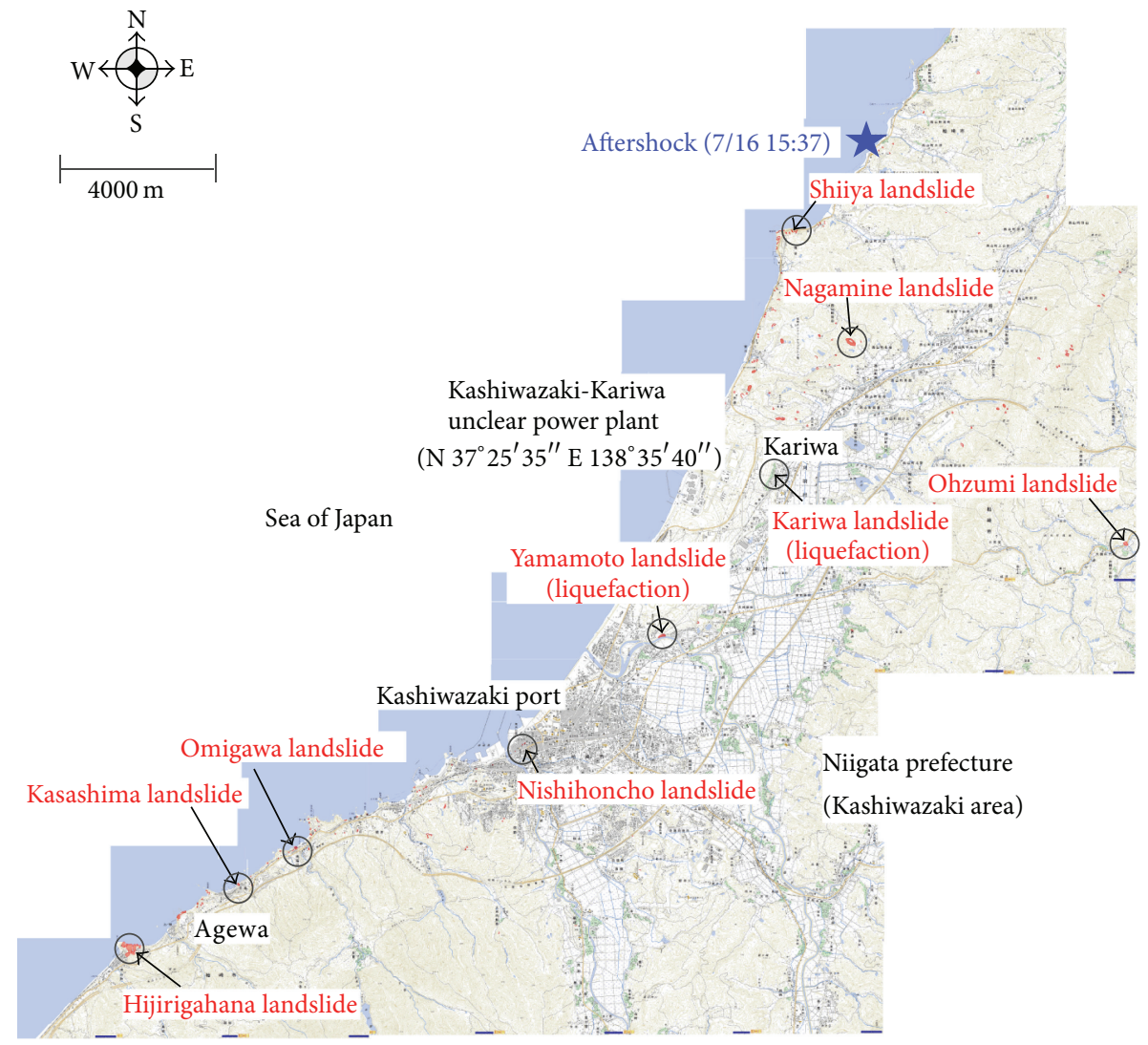

FIGURE 6: Landslide locations during the Mid-Niigata Offshore Earthquake (provided by GSI).

the snow remained deeper than $2 \mathrm{~m}$ in April in mountainous areas. According to the Niigata prefectural office, 19 slope failures threatening residential life were reported on $20 \mathrm{March}$ 2011. The slope failures were concentrated in Tokamachi city and Tsunan town, which have tertiary mudstone as their main geology (Figures 1 and 2). The Nagano prefectural office reported on 16 March 2011 that seven severe slope failures during the earthquake occurred in Sakae village, which has main geology of Andesitic rocks (Figures 1 and 2). Although the same type of earthquake occurred with 


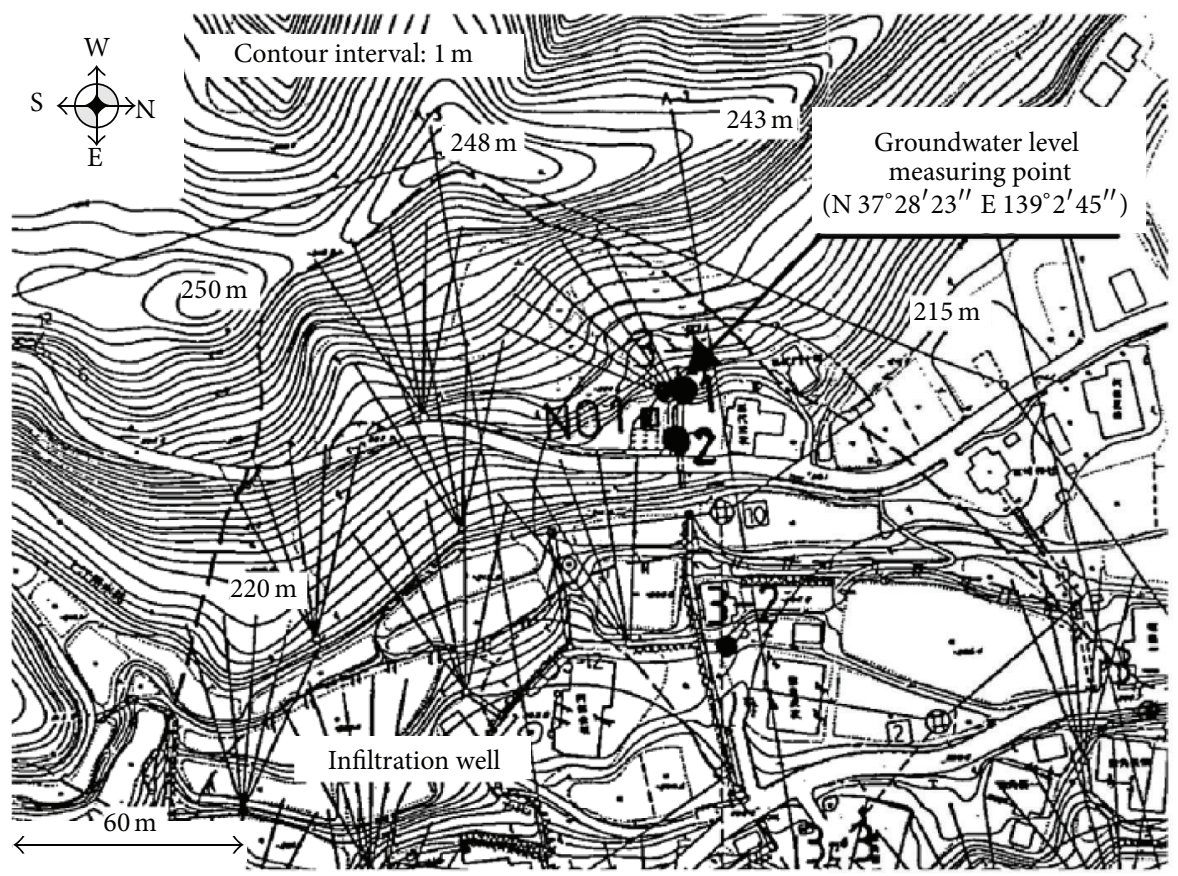

Figure 7: Topographical map (old landslide area at Tochio).

the Mid-Niigata Earthquake that occurred directly underneath the mountainous area, it remains unclear why so few earth disasters were generated by the earthquake.

\section{Importance of Groundwater Level}

Water level and pore water pressure have been measured at the author's laboratory since 1995 in the old landslide area at the former Tochio city (Figure 1). The data were acquired using a data logger every hour on the hour. A detailed topographical map of this area is presented in Figure 7. The observation point is inferred to be the upper part of the landslide. The gentle slope of a river terrace, which was formed by the meandering flow of river, spreads in the lower part of the landslide. Many infiltration wells have been made in this area as landslide countermeasures. After their installation, no remarkable mass movement has been reported to date. Figure 8 shows the depth of groundinstalled water pressure sensors and their geologic column. A borehole with a strainer, which is $27 \mathrm{~m}$ deep, was made in the slope. Then a water pressure transducer was set at $12 \mathrm{~m}$ depth in the borehole for estimation of water level. For pore water pressure measurement, a water-pressure transducer in the borehole was buried in sand. Their upper and lower sides were sealed with bentonite. The ground consists of soft silty soil up to $10.3 \mathrm{~m}$ deep from the surface and a sandy gravel layer of about $70 \mathrm{~cm}$. Soft underlying rock comprises sand and silt in sections deeper than $11 \mathrm{~m}$.

Figure 9 presents records of groundwater level and hourly rainfall at Tochio during the Mid-Niigata Earthquake.

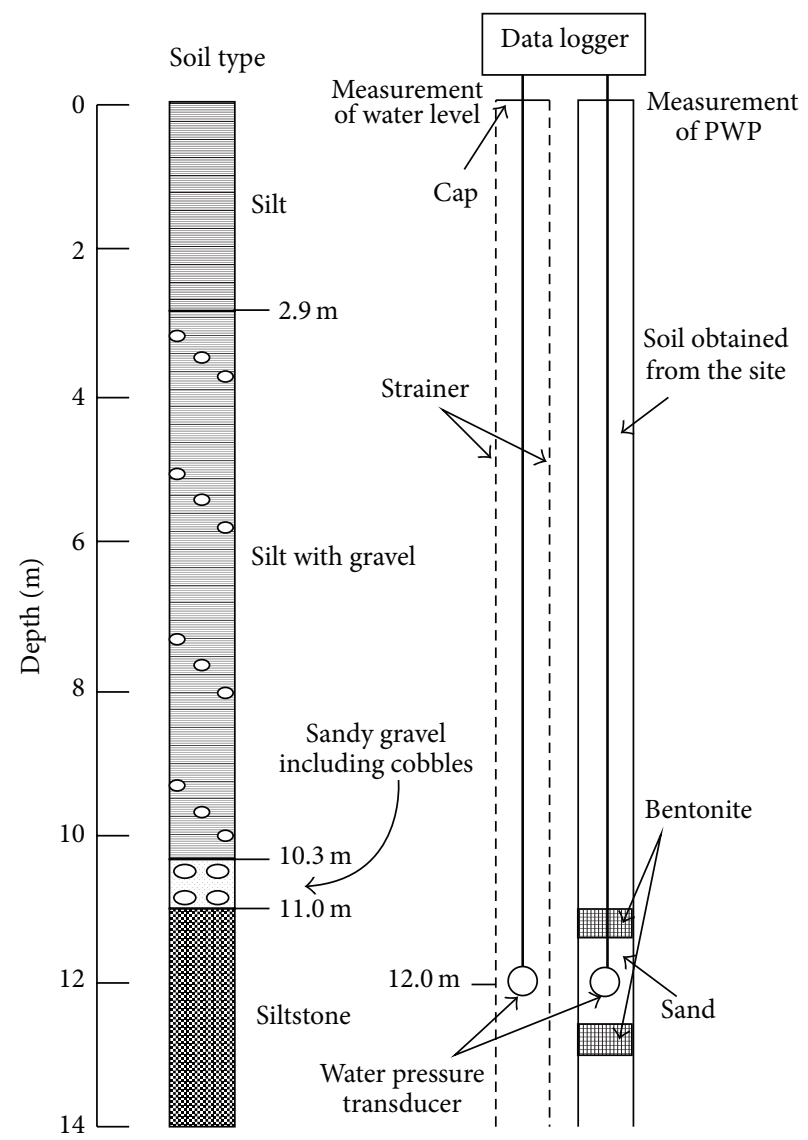

FIGURE 8: Depth of sensors and soil profiles. 


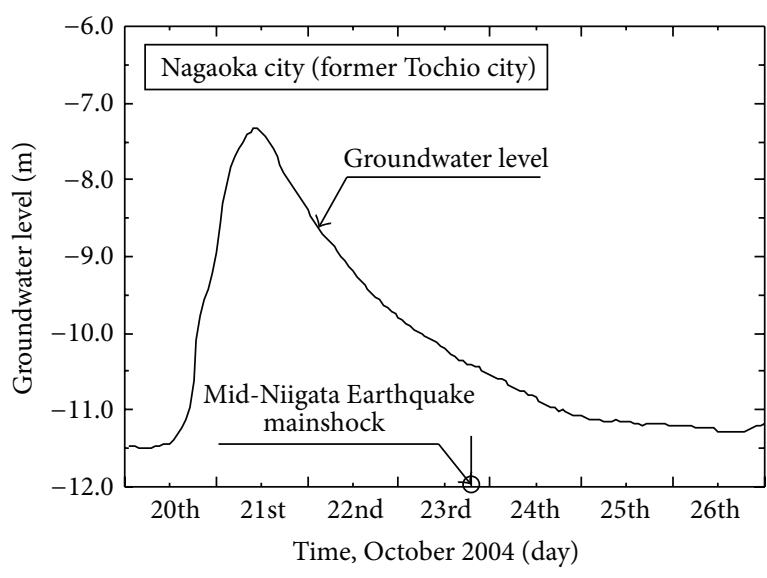

(a)

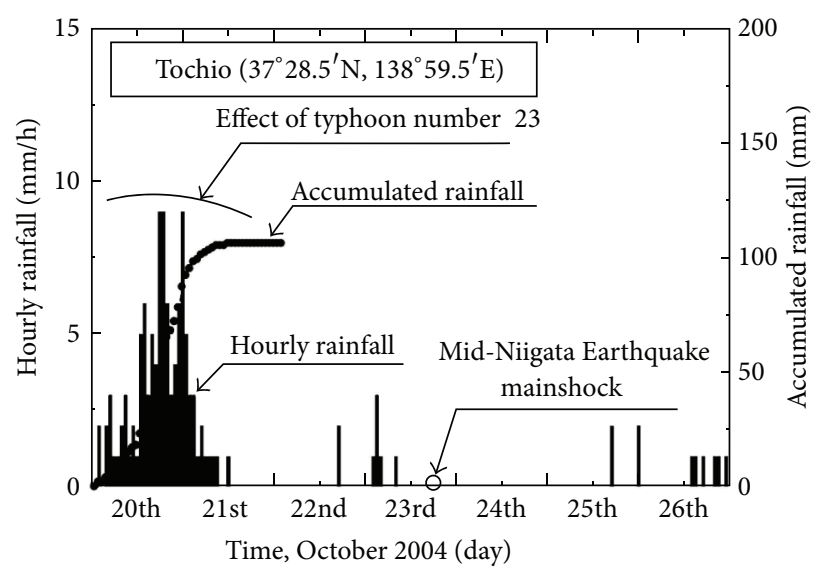

(b)

Figure 9: (a) Groundwater level and (b) rainfall during 20-26 October 2004.

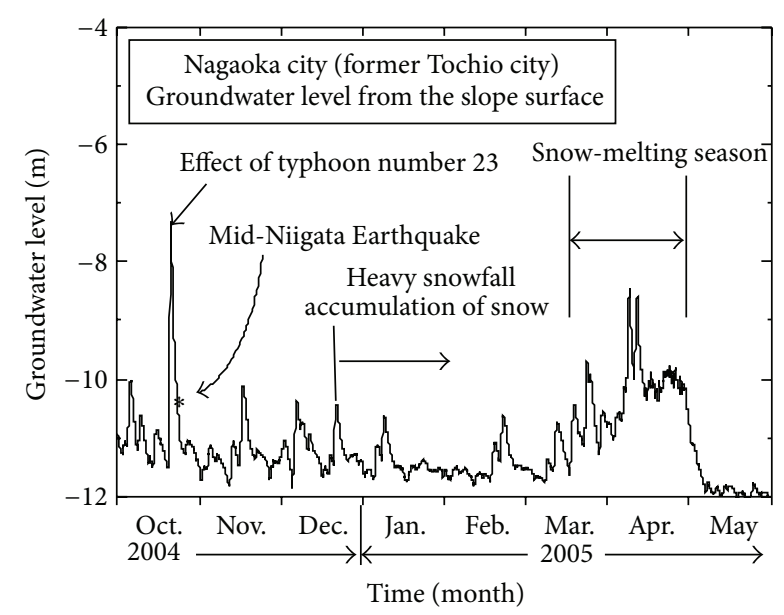

FIGURE 10: Groundwater level fluctuation.

Rainfall from typhoon number 23 occurred on 20 October 2004. The accumulated rainfall reached $100 \mathrm{~mm}$ in this area (Figure 9). The groundwater level rose quickly about $4 \mathrm{~m}$ with the rainfall. This area is inferred to include many catchment areas because the elevated groundwater levels descend gradually over a few days. The rise in the groundwater table induced by the typhoon had dropped by about $3 \mathrm{~m}$ in Tochio by the time of the Mid-Niigata Earthquake. It is apparent that this area still contained more water during the Mid-Niigata Earthquake than it did under ordinary conditions.

Groundwater level fluctuation (October 2004-May 2005) is shown in Figure 10. The groundwater level at three days before the Mid-Niigata Earthquake was the highest in the displayed period of time. The snow season starts from midDecember. The total amount of snowfall reached $699 \mathrm{~cm}$ at Nagaoka during that winter. Snow melting accelerates from March with the coming of spring. The groundwater level increases during the snow-melting season because of soaking of snow water and suddenly drops after snow melting (in May), as shown in Figure 10. For that reason, tertiary type landslides have occurred frequently in this area in April and
May: the snow-melting season. Therefore, it was feared that the slope damaged by the Mid-Niigata Earthquake starts moving again. Observations were continued during and after the snow season.

\section{Follow-Up of Damaged Slope}

The Chuetsu region is a heavy snow area. The risk of snow avalanche has been increasing because the Mid-Niigata Earthquake damaged snow-protection facilities and natural vegetation. According to Niigata prefecture, 228 avalanche mitigation fences and 8 snow sheds were damaged during the earthquake. Figure 11(a) shows an example of landslide in which soil mass slipped down with snow avalanche fences. Surface failures scoured the fence foundations. The fences were deformed because of falling soil. Soil accumulation behind fences and above snow sheds was also severe problem. As an emergency restoration, the accumulated soils were removed and large sandbags were emplaced to protect the infrastructure from the snow avalanche before the winter.

Snow avalanches occurred more frequently that year than in a normal winter. Some slopes were not covered with deep snow because a small snow slide occurred at all snowfalls. However, frequent patrols were conducted, preventing heavy damage. The risk of avalanche was reduced by the removal of unstable snow, construction of snow walls, and road closures during the winter. A new type of avalanche, where snow fell together with surface soil stripped from the damaged slope, was observed in Tokamachi City (Figure 1) as shown in Figure 11(b). An avalanche of this type, called a "snow-earth mixture avalanche," is regarded as a compound natural disaster, causing extensive damage to residences and roads [21].

Landslides have occurred frequently during the snowmelting season in this area because of high groundwater levels (Figure 10). Therefore, it was feared that the slope damaged by the Mid-Niigata Earthquake starts moving again as a secondary disaster. Therefore, after snow melting, follow-up investigations were conducted to observe the slope failure sites. However, Toyota [22] reported that no large mass 


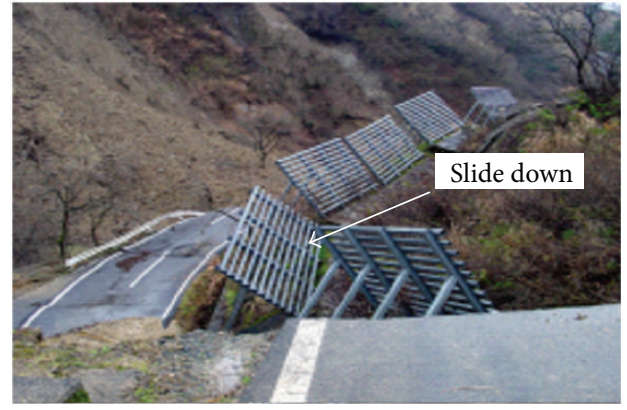

(a)

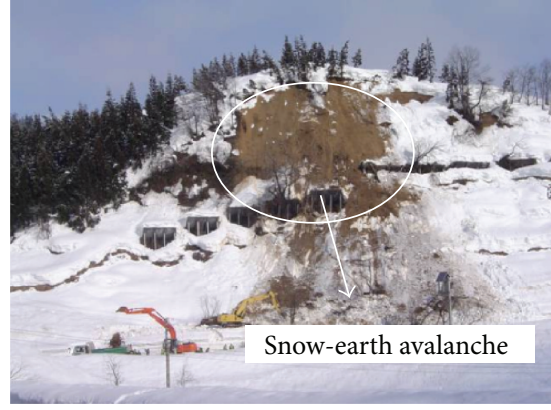

(b)

FIGURE 11: (a) Damage to snow avalanche fence; (b) snow-earth avalanche [21].

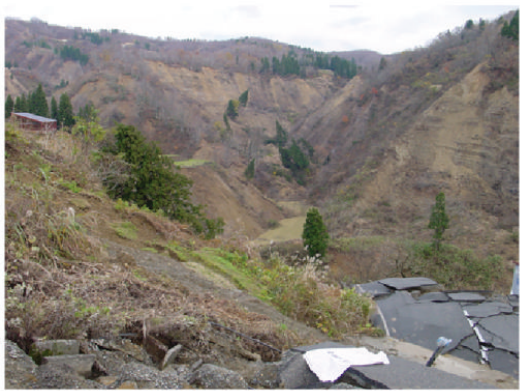

November 2004

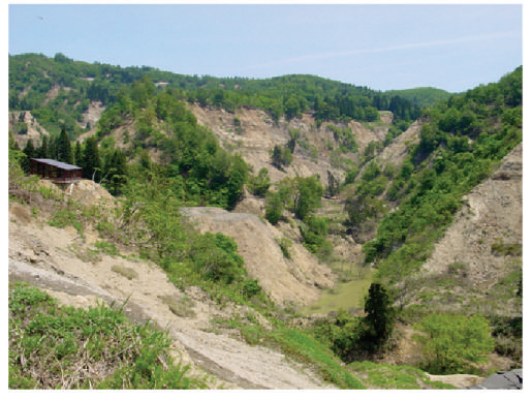

May 2005

(a) Nampei

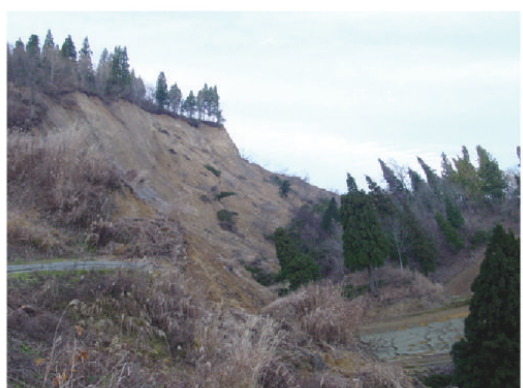

December 2004

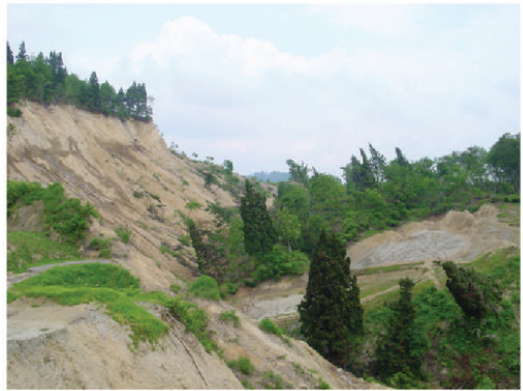

June 2005

(b) Shiodani

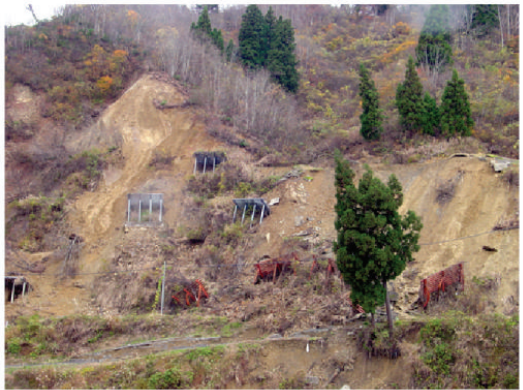

November 2004

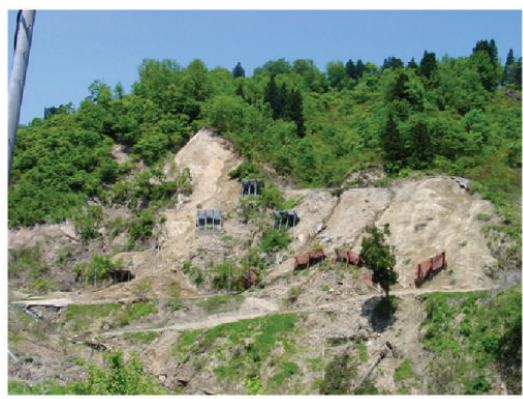

May 2005

(c) Iketani

FIGURE 12: Slope failures: upper row, before winter, and lower row, after snow-melting season.

movement occurred during the snow-melting season. These sliding masses induced by the Mid-Niigata Earthquake were therefore stable except for erosion from rain and snow melting. Situations of slope failures can be compared for those before winter and after the snow-melting season in Figure 12. There is no apparent difference between the photographs.

\section{Earthquake Damage Comparisons}

Comparisons between the Mid-Niigata Earthquake, the MidNiigata Offshore Earthquake, and the Northern Nagano Earthquake are presented in Table 3. All earthquakes are mutually similar except for the frequency of the aftershocks: they were frequent after the Mid-Niigata Earthquake, but not after other earthquakes. Many evacuees, to escape from the fear of repeated strong aftershocks, were compelled to reside for extended periods in inconvenient evacuation areas. Some were afflicted with phlebothrombosis, often called "economy class syndrome."

However, the types of damage related to the earth disaster were different among the earthquakes in spite of being only $60 \mathrm{~km}$ distant from the epicentre. Although the main landslide sites are hilly and mountainous areas and although more than 3,000 slope failures occurred during the Mid-Niigata Earthquake, 108 slope failures occurred mainly in the steep slope of the coastal terrace during the Mid-Niigata Offshore Earthquake according to a report of MLIT on 6 August 2007 because the earthquake occurred not under a mountainous area but under an offshore area. The Northern Nagano Earthquake occurred under mountainous areas between Nagano and Niigata. However, few landslides were reported, as described in Section 3.3. Two possible reasons can be considered. The first reason is that the main geology of Sakae Village in the northern part of Nagano is Andesitic rock, 
TABLE 3: Comparisons of earthquakes.

\begin{tabular}{llll}
\hline & Mid-Niigata & Mid-Niigata Offshore & Northern Nagano \\
\hline Date & 23 Oct. 2004 & 16 July 2007 & 12 March 2011 \\
Epicentre & Chuetsu area & Chuetsu offshore & Northern Nagano \\
Depth & $13 \mathrm{~km}$ depth & $17 \mathrm{~km}$ depth & $8 \mathrm{~km}$ depth \\
Cause & Thrust fault & Thrust fault & Thrust fault \\
Magnitude & M6.8 & M6.8 & M6.7 \\
JMA intensity & 7 (at Kawaguchi) & 6 upper (at Kashiwazaki) & 6 upper (Sakae) \\
Max. & 1750.2 gal & 812.7 gal & 803.5 gal \\
acceleration & (at Tokamachi) & (at Kashiwazaki) & (at Tsunan) \\
Aftershock & Frequent & Rare & Rare \\
Landslides & Thousands & Medium & Medium \\
\hline
\end{tabular}

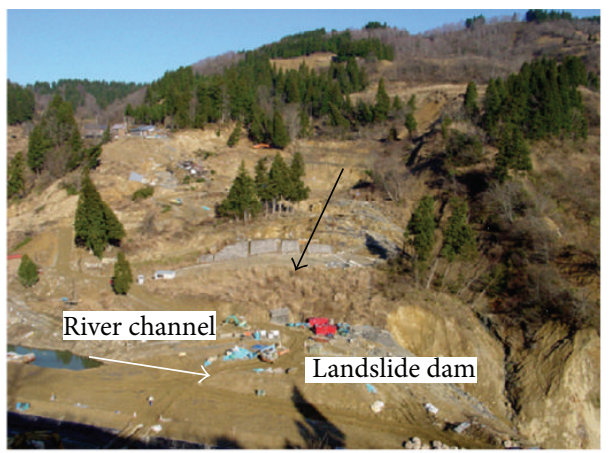

(a)

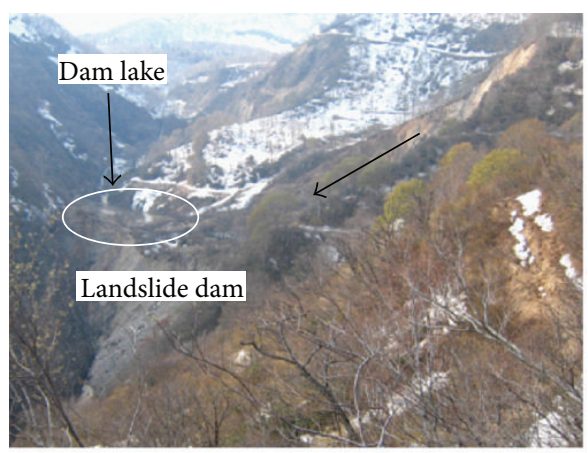

(b)

FIgURE 13: Typical river-clogging landslides that occurred (a) during the Mid-Niigata Earthquake and (b) during the Northern Nagano Earthquake.

which is different from the tertiary mudstone of the Chuetsu area (Figure 2). Examples of slope failures are exhibited in Figure 13. Figure 13(a) shows a river-clogging landslide at Yamakoshi area during the Mid-Niigata Earthquake. The weak soft deposit moved down and closed the Imo River channel. Figure 13(b) presents river-clogging landslides at Sakae Village during the Northern Nagano Earthquake. Apparently, the weathered part of a steep cliff fell and clogged a narrow valley. Then the dammed lake was created by the moving mass. However, the tertiary mudstone is distributed in Tokamachi and Tsunan areas (Figures 1 and 2) where strong seismic motion was recorded during the earthquake. Therefore, the second considered reason is that groundwater level might not be high during the Northern Nagano Earthquake compared with that of the Mid-Niigata Earthquake, as shown in Figure 9(a). From Figure 10, it is inferred that the ground water level remained low immediately before snow melting during the Northern Nagano Earthquake. Although snow remained deeper than $2 \mathrm{~m}$ in mountainous areas, few snow avalanches were triggered by the earthquake. Accumulated snow is apparently quite stable against earthquakes during this season (March). Consequently, the relations between the epicentre, the geography including geology, and groundwater level are extremely important factors to discuss to assess the risk of landslide damage.

\section{Conclusions}

Several earthquakes struck the Chuetsu area of Niigata successively in recent years. Damage investigations have been reported individually and have been mutually compared. Information about damage related to geotechnical engineering has been assembled and discussed from the viewpoint of compound natural disasters. Although no severe damage has been certified as a secondary disaster, these disasters underscore the possibility of compound natural disasters or slight damage such as erosion occurring in the damaged slopes. A summary of the main findings from the study is presented below.

(1) The importance of groundwater level during landslide disasters was assessed using field measurement results. Results show that groundwater during the Mid-Niigata Earthquake was higher than that under normal conditions.

(2) Large-scale landslides during the Mid-Niigata Earthquake were regarded as reactivated type landslides because they occurred on old landslide traces.

(3) Most landslides during the Mid-Niigata Earthquake occurred at alternating sandstone and mudstone strata, but landslides that moved gradually during 
the snow-melting season usually involved mudstone in large quantities from tertiary deposits.

(4) Landslides during the Mid-Niigata Offshore Earthquake were fewer than those which occurred during the Mid-Niigata Earthquake, perhaps because the main tremor occurred not under a mountainous area but under an offshore area during the Mid-Niigata Offshore Earthquake.

(5) Landslides that occurred during the Northern Nagano Earthquake were also fewer than those that occurred during the Mid-Niigata Earthquake. The reasons considered are that the main geology of the mountainous area in northern Nagano is not tertiary mudstone but Andesitic rock. Moreover, the groundwater level might not be high compared to that prevailing during the Mid-Niigata Earthquake. Only a few snow avalanches triggered by the earthquake were reported in spite of snow that remained on the ground.

(6) The risk of snow avalanche increased after the earthquakes because snow-protection facilities and natural vegetation were damaged.

(7) Some additional damage occurred such as surface erosion and surface slides during rainfall and snowmelting season in the slopes damaged and loosened by the earthquakes. Carefully conducted daily observations are important to prevent a secondary disaster because some indications (slight damage) will precede severe damage. Timely countermeasures taken for cases of slight damage must be taken to reduce the risk of severe damage.

\section{Conflict of Interests}

The authors declare that there is no conflict of interests regarding the publication of this paper.

\section{References}

[1] Japan Society of Civil Engineers, Ed., Report on the 2004 Niigata Chuetsu Earthquake, CD Rom, Japan Society of Civil Engineers, 2006, (Japanese).

[2] H. Toyota, J. Wang, K. Nakamura, and N. Sakai, "Evaluation of natural slope failures induced by the 2004 Niigata-ken Chuetsu Earthquake," Soils and Foundations, vol. 46, no. 6, pp. 727-738, 2006.

[3] Y. Tsukamoto, K. Ishihara, and Y. Kobari, "Evaluation of runout distances of slope failures during 2004 Niigata-ken Chuetsu Earthquake," Soils and Foundations, vol. 46, no. 6, pp. 713-725, 2006.

[4] E. Rathje, R. Kayen, and K.-S. Woo, "Remote sensing observations of landslides and ground deformation from the 2004 Niigata Ken Chuetsu earthquake," Soils and Foundations, vol. 46, no. 6, pp. 831-842, 2006.

[5] M. Chigira and H. Yagi, "Geological and geomorphological characetristics of landslides triggered by the 2004 mid Niigata prefecture earthquake in Japan," Engineering Geology, vol. 82, no. 4, pp. 202-221, 2006.
[6] H. B. Wang, K. Sassa, and W. Y. Xu, "Analysis of a spatial distribution of landslides triggered by the 2004 Chuetsu earthquakes of Niigata Prefecture, Japan," Natural Hazards, vol. 41, no. 1, pp. 43-60, 2007.

[7] A. Onoue, A. Wakai, K. Ugai et al., "Slope failures at Yokowatashi and Nagaoka College of Technology due to the 2004 Niigataken Chuetsu Earthquake and their analytical considerations," Soils and Foundations, vol. 46, no. 6, pp. 751-764, 2006.

[8] J. Deng, H. Kameya, Y. Miyashita, J. Kuwano, R. Kuwano, and J. Koseki, "Study on dip slope failure at Higashi Takezawa induced by 2004 Niigata-Ken Chuetsu earthquake," Soils and Foundations, vol. 51, no. 5, pp. 929-943, 2011.

[9] K. Sassa, H. Fukuoka, G. Scarascia-Mugnozza, and S. Evans, "Earthquake-induced landslides: distribution, motion and mechanisms," Soils and Foundations, pp. 53-64, 1996.

[10] N. M. Newmark, "Effects of earthquakes on dams and embankments," Géotechnique, vol. 15, no. 2, pp. 139-160, 1965.

[11] Japanese Geotechnical Society, Ed., Report on the 2007 Niigataken Chuetsu-oki Earthquake, Japanese Geotechnical Society, 2009, (Japanese).

[12] A. Onoue and H. Toyota, "Damage induced by the 2007 Niigataken Chuetsu-oki earthquake," in Proceedings of the 14th World Conference on Earthquake Engineering, Paper ID: S26-15, pp. 18, Beijing, China, 2008.

[13] H. Toyota and A. Onoue, "Characterisation of slope failures during the 2004 Niigata-ken Chuetsu and the 2007 Niigataken Chuetsu-oki Earthquake," in Proceedings of the 14th World Conference on Earthquake Engineering, PaperID: S26-18, pp. 18, Beijing, China, 2007.

[14] Joint Editorial Committee for the Report on the Great East Japan Earthquake Disaster, Report on the Great East Japan Earthquake Disaster, Fundamental Aspects 3, Geohazards (Abstract), JGS, 2014, (Japanese).

[15] Japan Metrological Agency, "Report on the Northern Nagano Earthquake (2nd issue)," 2011, http://www.jma.go.jp/jma/press/ 1103/12d/201103120800.html.

[16] Niigata Branch of the Japan Landslide Society, Ed., Record of Landslide Disasters in Niigata, CD Rom, Niigata Branch of the Japan Landslide Society, 2003, (Japanese).

[17] Editorial Committee of History of Yamakoshi Village, History of Yamakoshi Village, Editorial Committee of History of Yamakoshi Village, Yamakoshi, Japan, 1981, (Japanese).

[18] National Research Institute for Earth Science and Disaster Prevention (NIED) and Japan Science and Technology Agency (JST), "Landslide map," 2004, http://lswebl.ess.bosai.go.jp/jisuberi/jisuberi_mini/jisuberi_top.html.

[19] K. Takeuchi, Y. Yanagisawa, J. Miyazaki, and M. Ozaki, "1:50,000 digital geological map of the Uonuma region, Niigata Prefecture (Ver. 1)," GSJ Open-File Report 412, 2004, http://www.gsj.jp/ GDB/openfile/files/no0412/index.html.

[20] Niigata Prefecture, Ed., Conservation Map, Niigata Prefecture, Niigata, Japan, 1982, (Japanese).

[21] I. Kamiishi and M. Machida, "Snow avalanche by the Chuetsu Earthquake and heavy snow," in Earthquake Disaster and Prevention in Snowy Areas, pp. 45-67, Japan Society for Snow Engineering, Joshinetsu, Japan, 2008, (Japanese).

[22] H. Toyota, "Stability progress of slopes damaged by natural disaster-case study in the Chuetsu area of Niigata, Japan," in Proceedings of the 17th Southeast Asian Geotechnical Conference, vol. 2, pp. 113-122, Taipei, Taiwan, 2010. 

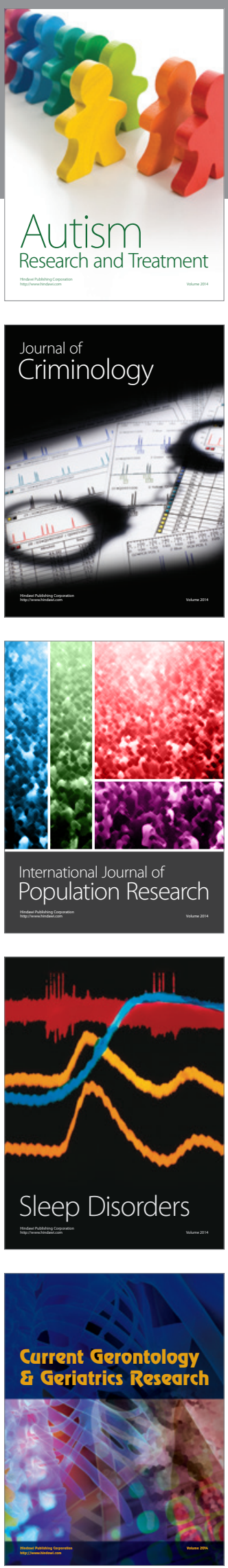
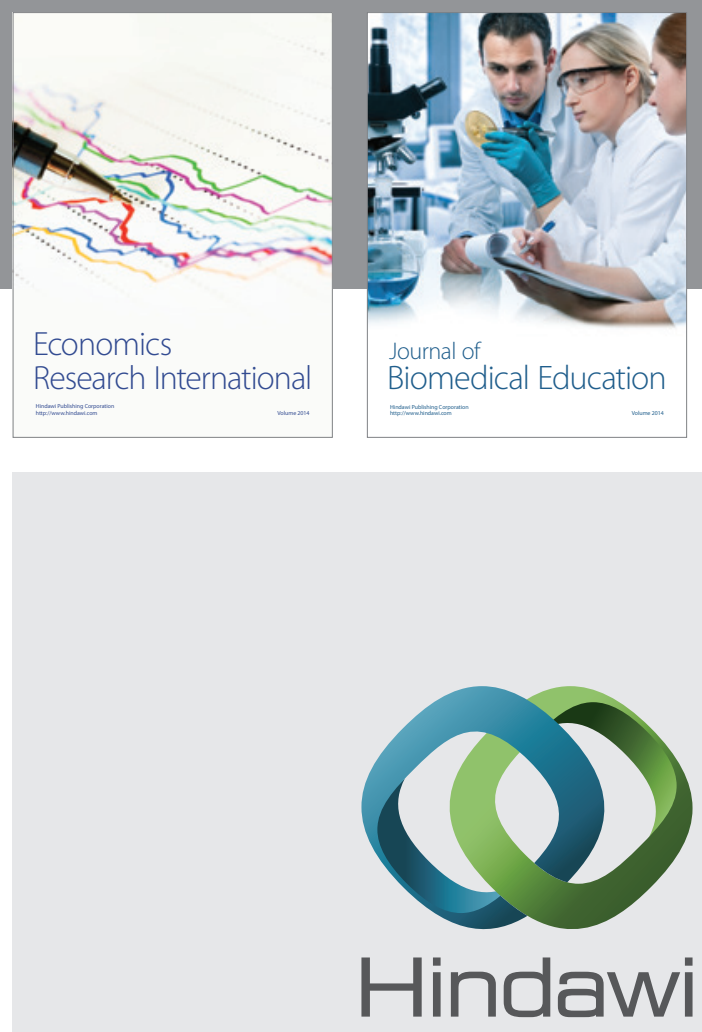

Submit your manuscripts at

http://www.hindawi.com
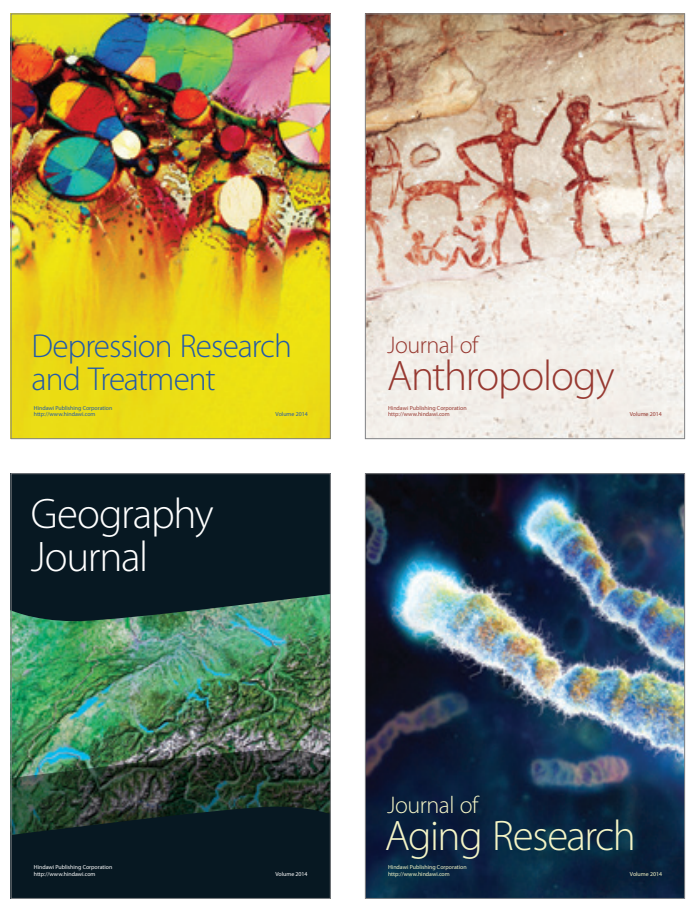
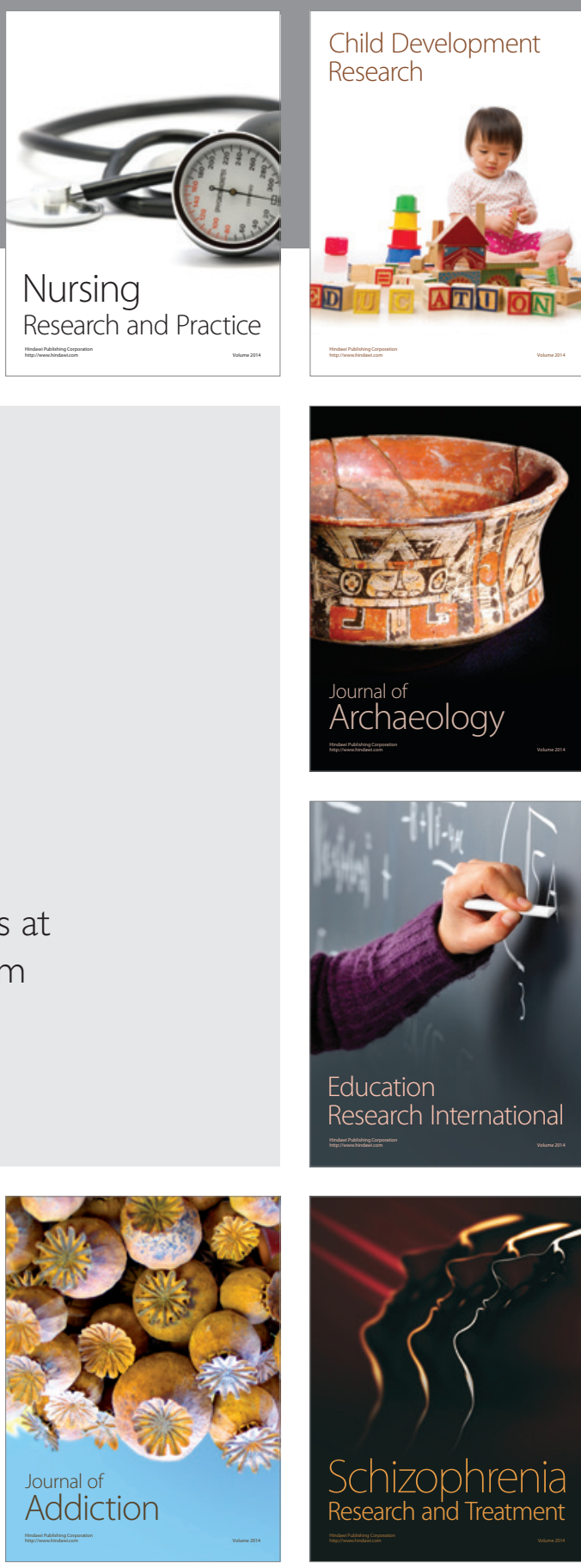

(D)
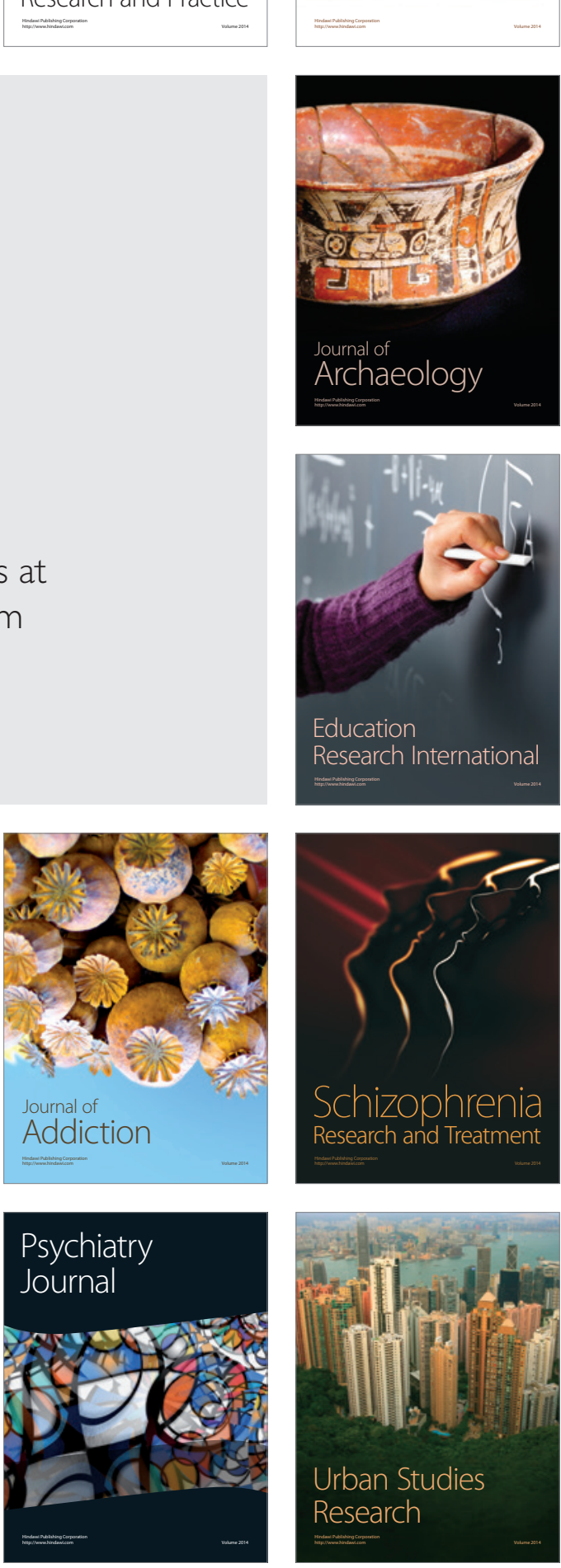